\title{
Effect of feeding broiler chicken on soybean oil and palm oil supplemented with some feed additives on the quality characteristics of processed chicken nuggets
}

\author{
Engy F. Zaki ${ }^{1 *}$, El Faham A.I²., Nematallah G.M. ${ }^{2}$ \\ ${ }^{1}$ Meat Production and Technology Unit, Animal Breeding Department, Desert Research Center, Cairo, Egypt. \\ ${ }^{2}$ Poultry Production Department, Faculty of Agriculture, Ain Shams University, Cairo, Egypt.
}

\begin{abstract}
The objective of this study was to investigate the effect of feeding broiler chicken on different vegetable oils with feed additives on the quality characteristics of chicken nuggets. A total of 216 one-day-old chicks of (Hubbard) strain were randomly assigned to six dietary treatments as $(2 \times 3)$ factorial designs where two sources of dietary oil contained soybean oil and palm oil with three levels of commercial multi-enzyme feed additives. Treatments were: soybean oil only (T1), soybean oil $+Z A D(T 2)$, soybean oil+ AmPhi-BACT (T3), palm oil only (T4), palm oil + ZAD (T5) and palm oil + AmPhi-BACT (T6). Results showed that chicken nuggetsof T3 group had the higher $p H$ value. No significant differences were found in cooking loss between (T1, T5 andT6) and nuggets of T3and T4. Nugget of T2 group had the higher T.B.A value. No significant effect on shrinkage \% of nuggets samples.
\end{abstract}

Keywords-Broiler feed, Vegetable oils, Feed additives, Chicken nuggets, Quality characteristics.

\section{INTRODUCTION}

Chicken meat contains a high protein and low fat content and deliberated as the principal source of polyunsaturated fatty acids (PUFA) with paramount concentration of n-3 PUFA (Howe et al., 2006).

Chicken has been considered an appropriate model in lipid nutrition studies, since it is highly sensitive to dietary fat modifications and many of the studies done with chickens deal with the degree of saturation or source type of the dietary replaced fat and how it influences the performance and carcass quality improvement of the animal (Rymer and Givens, 2005).

Using soybean and palm oil in poultry rations would subsequently affect human health in a positive manner by increasing 18:2 and 18:3 fatty acid contents in animal product without any negative effects on meat quality (Ayed et al., 2015).Palm oil can be used as a vegetable oil in broiler chicken nutrition with positive effects on firmness of meat quality compared with soybean oil and linseed oil (Abdulla et al., 2015).

Commercial enzyme preparations have been used widely to enhance nutritive value of wheat and rye-based diets because of high insoluble non-starch polysaccharides found in these feedstuffs which induce high digesta viscosity (Lázaro et al., 2003). Inclusion of exogenous enzyme in animal's diet has been shown to improve broiler's performance. But the effect on meat quality has to be determined as certain feed additives have been found to affect meat quality (Wang, et al., 2013; Omojola, et al., 2014).

Therefore, this research aims to study the effect of using different vegetable oil sources and feed additives in finisher diets of broiler chicken, on the quality characteristics and lipid oxidation of processed chicken nuggets.

\section{MATERIAL AND METHOD}

\section{$2.1 \quad$ Experimental Design}

The experimental procedures were approved by the Poultry Production Department, Faculty of Agriculture, Ain Shams University and as followed by the Animal Breeding Department, Animal and Poultry Production Division, Desert Research Center.

The current study was conducted at Poultry Experimental Unit, Faculty of Agriculture, Ain Shams University, located in Agricultural Research Station, Shalaqan, Qalyobia Governorate, Egypt. The experiment was a $2 \times 3$ factorial design with two sources of vegetable oils (soybean oil and palm oil) with three levels of commercial multi-enzyme feed additives as shown in the Table (1). 
Table.1: Experimental design

\begin{tabular}{llll}
\hline & & Feed additives & \\
\hline Type of oil & Without addition & ZAD $^{1} 0.5 \mathrm{~kg} /$ ton & AmPhi-BACT \\
\cline { 2 - 4 } Soybean oil & Treatment 1 (T1) & Treatment 2 (T2) & Treatment 3 (T3) \\
Palm oil & Treatment 4 (T4) & Treatment 5 (T5) & Treatment 6 (T6)
\end{tabular}

1 (ZAD) which contains bacteria (Ruminococcusflavefaciens) with concentration of $\left(28 \times 10^{4}\right)$. Also it contains a mixture of enzymes (Cellulase - Xylanase - $\alpha$-Amylase -Protease).

${ }^{2}$ (AmPhi-BACT), which contains bacteria (Lactobacillus acidophilus) and (Lactobacillus planterum) and (Bifidobacteriumbifidum) and extract ferment of both (Bacillus subtilus) and (Aspergillusniger) with concentration of $5 \mathrm{~g} / \mathrm{kg}$ and also contains a mixture of enzymes that is estimated as 34.5 units / gram, that is equivalent to $2 \mathrm{~g} / \mathrm{kg}$ (Cellulase - Beta-glucanase - Hemicellulase ).

A total of 216 one-day-old chicks of (Hubbard) strain were used for this study, the chicks were randomly assigned to six treatment groups. Each group consisted of six replicates and each replicate was made up of six chicks. The basal diet was formulated to meet the nutrient requirements of broiler chicken following the National Research Council (NRC, 1994) as shown in Table (2).

Table.2: Feed ingredients and chemical analyses of experimental diets

\begin{tabular}{|c|c|c|c|c|c|c|c|c|}
\hline \multirow[b]{2}{*}{ Ingredients } & \multirow{2}{*}{$\begin{array}{l}\text { Starter } \\
(0-11)\end{array}$} & \multirow{2}{*}{$\begin{array}{l}\text { Grower } \\
(12-22)\end{array}$} & \multicolumn{6}{|c|}{ Finisher (23-35) } \\
\hline & & & $\mathrm{T} 1$ & $\mathrm{~T} 2$ & $\mathrm{~T} 3$ & $\mathrm{~T} 4$ & T5 & T6 \\
\hline Corn (grains) & 52.05 & 55.91 & 56.80 & 56.80 & 56.80 & 56.80 & 56.80 & 56.80 \\
\hline Soybean Meal (44\%) & 31.50 & 30.00 & 28.25 & 28.25 & 28.25 & 28.25 & 28.25 & 28.25 \\
\hline Corn Gluten Meal (62\%) & 7.20 & 4.86 & 4.40 & 4.40 & 4.40 & 4.40 & 4.40 & 4.40 \\
\hline Soybean Oil & 3.00 & 3.65 & 5.00 & 5.00 & 5.00 & - & - & - \\
\hline Palm Oil & - & - & - & - & - & 5.00 & 5.00 & 5.00 \\
\hline Wheat Bran & 2.00 & 1.50 & 2.00 & 2.00 & 2.00 & 2.00 & 2.00 & 2.00 \\
\hline Di-Calcium Phosphate & 1.85 & 1.60 & 1.34 & 1.34 & 1.34 & 1.34 & 1.34 & 1.34 \\
\hline Calcium Carbonate & 1.30 & 1.50 & 1.35 & 1.35 & 1.35 & 1.35 & 1.35 & 1.35 \\
\hline Premix* & 0.30 & 0.30 & 0.30 & 0.30 & 0.30 & 0.30 & 0.30 & 0.30 \\
\hline Salt $(\mathrm{NaCl})$ & 0.30 & 0.30 & 0.30 & 0.30 & 0.30 & 0.30 & 0.30 & 0.30 \\
\hline DL-Methionine & 0.29 & 0.28 & 0.21 & 0.21 & 0.21 & 0.21 & 0.21 & 0.21 \\
\hline L-Lysine HCL & 0.21 & 0.10 & 0.05 & 0.05 & 0.05 & 0.05 & 0.05 & 0.05 \\
\hline Total & 100 & 100 & 100 & 100 & 100 & 100 & 100 & 100 \\
\hline \multicolumn{9}{|c|}{ Nutrient content (Calculated) $* *$} \\
\hline Crude Protein $\%$ & 23.00 & 21.00 & 20.00 & 20.00 & 20.00 & 20.00 & 20.00 & 20.00 \\
\hline Crude Fat \% & 5.69 & 6.39 & 7.76 & 7.76 & 7.76 & 7.76 & 7.76 & 7.76 \\
\hline Crude Fiber $\%$ & 3.88 & 3.75 & 3.70 & 3.70 & 3.70 & 3.70 & 3.70 & 3.70 \\
\hline ME Kcal/ Kg diet & 3029 & 3076 & 3171 & 3171 & 3171 & 3171 & 3171 & 3171 \\
\hline Calcium \% & 1.00 & 1.01 & 0.90 & 0.90 & 0.90 & 0.90 & 0.90 & 0.90 \\
\hline Available Phosphorus \% & 0.50 & 0.45 & 0.40 & 0.40 & 0.40 & 0.40 & 0.40 & 0.40 \\
\hline Lysine \% & 1.30 & 1.15 & 1.06 & 1.06 & 1.06 & 1.06 & 1.06 & 1.06 \\
\hline Methionine \&Cystein \% & 0.97 & 0.93 & 0.84 & 0.84 & 0.84 & 0.84 & 0.84 & 0.84 \\
\hline
\end{tabular}

* Each 3 Kg of premix contains: Vitamins: A: $12000000 \mathrm{IU}$; Vit. D3 2000000 IU; E: 10000 mg; K3: 2000 mg; B1:1000 mg; B2: $5000 \mathrm{mg}$; B6:1500 mg; B12: $10 \mathrm{mg}$; Biotin: $50 \mathrm{mg}$; Coline chloride: $250000 \mathrm{mg}$; Pantothenic acid: $10000 \mathrm{mg}$; Nicotinic acid: 30000 mg; Folic acid: 1000 mg; Minerals: Mn: 60000 mg; Zn: 50000 mg; Fe: 30000 mg; Cu: 10000 mg; I: 1000 mg; Se: 100 mg and Co: $100 \mathrm{mg}$.

** Nutrient content calculated based on chemical analysis data of feedstuffs provided by NRC (1994). 
- Starter: one-day-old till 11 days-of-age (basal diet - without additives - all birds).

- Grower: 12 days till 22 days (basal diet - without additives - all birds).

- Finisher: 23 days till 35 days (experimental diets specified per treatment).

Chicks were housed in galvanized cages, where nine birds were allotted to a pen cage of $100 \mathrm{~cm}$ long, $40 \mathrm{~cm}$ width and $40 \mathrm{~cm}$ height. The farm building was aerated naturally. Lighting program was controlled to provide 23 hours light and one hour dark daily by candescent bulb lighting system. Room temperature was maintained around $32^{\circ} \mathrm{C}$ for the first week and was decreased by $3^{\circ} \mathrm{C}$ weekly afterwards.

At the end of experiment, four chickens were randomly selected for slaughtering from each treatment to use in the processing of chicken nuggets. Slaughtered birds were scalded in hot water bath, plucked and eviscerated manually. Chicken meat from thigh and abdominal muscles were collected, packed and frozen at $-18^{\circ} \mathrm{C}$ until further analyses and processing of chicken burger were completed.

\subsection{Preparation of chicken nuggets}

Chicken meat from each experimental diet was ground through a $3 \mathrm{~mm}$ plate grinder. Chicken nuggets samples were prepared as follows ingredients; wheat flour 3\%, Condiments $3 \%$, black pepper $2 \%$, Salt $1.5 \%$, and Ice flakes $8 \%$ as describe by (Nayak et al., 2015). Batches of $2 \mathrm{~kg}$ of each dietary treatment were mixed and formed by hand into circular ( $1 \mathrm{~cm}$ thicknes, $5 \mathrm{~cm}$ diameter and $25 \pm 2 \mathrm{~g}$ weight). Nuggets were placed in plastic foam trayspacked in polyethylene bags and frozen at $-18^{\circ} \mathrm{C} \pm 1$ until further analysis.

2.3 Physical analysis

\subsection{1 $\mathrm{pH}$ value}

$\mathrm{pH}$ of raw chicken nuggets was measured as described by Hood(1980). Ten grams of sample was homogenized with $100 \mathrm{ml}$ distilled water and measured using a digital $\mathrm{pH}-$ meter Jenway 3310 conductivity and $\mathrm{pH}$ meter. $\mathrm{pH}$ values were done on four replicates per treatment. Two nuggets were used for each replication.

\subsubsection{Cooking measurements}

Chicken nuggets samples of each treatment were dipped sequentially in plain flour and bread crumbs and fried in corn oil at $180{ }^{\circ} \mathrm{C}$ till golden brown in color. All cooking measurements were done on four replicates per treatment. For each replication three nuggets were examined for cooking loss, reduction in thickness, reduction in diameter and shrinkage.

The cooking loss was determined as reported by Naveena $e t$ al. (2006) as follows:

Cooking loss $(\%)=$

(Uncooked sample weight) - (Cooked sample weight) $\times 100$

(Uncooked sample weight)

\subsubsection{Shrinkage measurements}

Raw and cooked samples were measured for diameter and thickness of chicken nuggets as described byBerry (1993) using the following equation: Reduction in diameter $(\%)=$ (Uncooked sample diameter)- (Cooked sample diameter)

(Uncooked sample diameter) $\times 100$

Reduction in thickness $(\%)=$

(Uncooked sample thickness) - (Cooked sample thickness)

(Uncooked sample thickness) $\times 100$

Shrinkage (\%): Dimensional shrinkage was calculated using the following equation as reported by Murphy et al. (1975): $=\underline{(\text { Raw thickness }- \text { Cooked thickness })+(\text { Raw diameter }-}$ Cooked diameter) $\times 100 /$ (Raw thickness + Raw diameter $)$

\subsection{T.B.A value}

Measurement of lipid oxidation: The extent of lipid oxidation in raw chicken nuggets was assessed by measuring 2- thiobarbituric acid reactive substances (TBARS), as described by AOCS (1998).TBA values were done on three replicates per treatment. Three nuggets were used in each replication.

\subsection{Color measurements}

Color of raw chicken nuggets samples was measured by Chroma meter (Konica Minolta, model CR 410, Japan) calibrated with a white plate and light trap supplied by the manufacturer (CIE, 1976). The color was expressed as L* (lightness), $\mathrm{a}^{*}$ (the redness) and $\mathrm{b}^{*}$ (the yellowness). The average of three spectral readings at different locations was obtained for each treatment.

\subsection{Statistical analysis}

Analysis of variance (ANOVA) was used to test the obtained data using the general linear modeling procedure (SAS, 2000). The used design was one way analysis. Duncan's multiple tests (1955) were applied for comparison of means.

\section{RESULTS AND DISCUSSION}

Table (3) showed the physiochemical properties of chicken nuggets processed from broiler chicken fed on different types of vegetable oil and feed additives. Chicken nuggets of T3 group had the higher $\mathrm{pH}$ value (6.11) followed by nugget of T5 (6.10). Slight differences were found between other nuggets samples. 
Table.3: Physicochemical properties of chicken nuggets

\begin{tabular}{cccc}
\hline & \multicolumn{3}{c}{ Parameters } \\
\cline { 2 - 4 } Treatments & $\mathrm{pH}$ & Cooking loss $(\%)$ & T.B.A $(\mathrm{mgMDA} / \mathrm{kg})$ \\
\cline { 2 - 4 } T1 & $6.05 \pm 0.04^{\mathrm{bcd}}$ & $16.51 \pm 0.89^{\mathrm{c}}$ & $0.061 \pm 0.016^{\mathrm{c}}$ \\
T2 & $6.02 \pm 0.03^{\mathrm{cd}}$ & $27.25 \pm 0.49^{\mathrm{a}}$ & $0.156 \pm 0.004^{\mathrm{a}}$ \\
T3 & $6.11 \pm 0.02^{\mathrm{a}}$ & $22.97 \pm 1.55^{\mathrm{b}}$ & $0.048 \pm 0.008^{\mathrm{cd}}$ \\
T4 & $6.00 \pm 0.03^{\mathrm{d}}$ & $21.08 \pm 2.71^{\mathrm{b}}$ & $0.059 \pm 0.005^{\mathrm{c}}$ \\
T5 & $6.10 \pm 0.03^{\mathrm{ab}}$ & $15.85 \pm 2.29^{\mathrm{c}}$ & $0.088 \pm 0.001^{\mathrm{b}}$ \\
T6 & $6.06 \pm 0.06^{\mathrm{abc}}$ & $14.20 \pm 1.02^{\mathrm{c}}$ & $0.035 \pm 0.006^{\mathrm{d}}$ \\
SEM & 0.01 & 0.97 & 0.004 \\
\hline
\end{tabular}

a-d means within the same column with different superscripts letters are different $(\mathrm{p}<0.05)$. T1, T2 and T3: Treatments for soybean oil/ soybean oil with ZAD $0.5 \mathrm{~kg} / \mathrm{ton}$ and soybean oil with AmPhi-BACT 0.5kg/ton. T4, T5andT6: Treatments for palm oil/ palm oil with ZAD $0.5 \mathrm{~kg} / \mathrm{ton}$ and palm oil with AmPhi-BACT $0.5 \mathrm{~kg} / \mathrm{ton}$. Means \pm standard deviation. SEM: standard error of means.

Pekel et al. (2012) found that the $\mathrm{pH}$ of breast meat did not differ between broilers that were fed soybean oil (SO) and the neutralized sunflower soapstock (NSS) diet. Addition of commercial multi-enzyme feed additives had a significant effect on $\mathrm{pH}$ value of nugget processed from broiler chicken fed on soybean oil (T2 and T3), while no significant difference were found on those fed on palm oil ( $\mathrm{T} 5$ and $\mathrm{T} 6$ ). These results are close to that obtained by Zakaria et al. (2010) they reported that enzymes addition had no effect on $\mathrm{pH}$ value of broiler chicken meat. However the effect of dietary enzyme on $\mathrm{pH}$ value of chicken meat was difficult to understand.

Data of cooking loss of chicken nuggets processed from broiler chicken fed on different types of vegetable oil and feed additives indicated that nugget of T2grouphad the higher cooking loss. No significant differences were found in cooking loss between(T1, T5 andT6) and nuggets of T3and T4. These results are close to that obtained by Pekel et al. (2012) they indicated that dietary fat source did not affect cooking loss of chicken meat.

As can be seen, addition of commercial multi-enzyme feed additives with palm oil had a significant effect on cooking loss of T2and T3 nuggets, while addition of feed additives with palm oil had no significant effects on cooking loss of T5andT6 nuggets. Omojola et al. (2014) found that chicken fed diets containing sesame and soybean diet supplemented with enzymes had higher cooking loss than those on sesame and soybean diet without enzymes. While, Zakaria et al. (2010) found that dietary enzyme had no effect on cooking loss of broiler chicken meat.

Data of T.B.A value of nuggets processed from broiler chicken fed on different types of vegetable oil and feed additives were showed in Table (3). Nugget processed from $\mathrm{T} 2$ group had the higher T.B.A value followed by nugget of $\mathrm{T} 5$, while the lowest T.B.A value found in nuggets of T6 group. No significant differences were found in T.B.A value of other nugget samples (T1, T3 and T4). These results are close to that obtained by Abdulla et al. (2015) they found that a significant difference in lipid oxidation was observed among the dietary oils. Breast muscles from broilers fed a diet supplemented with palm oil had a lower TBARS value compared with soybean oil. Also, Pekel et al. (2012) found that no significant differences were found in T.B.A value of thigh meat from broilers fed diets with different levels of fat from soybean oil or neutralized sunflower soapstock.

Data in Table (4) showed the shrinkage measurements of chicken nuggets processed from broiler fed on different types of vegetable oil and feed additives. Nugget of T2group had the higher reduction in diameter; slight significant differences were found in nugget of $\mathrm{T} 1$ group and nugget of T3 group. Also, no significant differences were found in nuggets samples of other dietary treatments $\mathrm{T} 4$, T5 and T6). 
Table.4: Shrinkage measurements of chicken nuggets

\begin{tabular}{cccc}
\hline & \multicolumn{3}{c}{ Parameters (\%) } \\
\cline { 2 - 4 } Treatments & Reduction in diameter & Reduction in thickness & Shrinkage \\
\cline { 2 - 4 } T1 & $14.13 \pm 1.40^{\mathrm{b}}$ & $12.28 \pm 1.47^{\mathrm{c}}$ & $17.93 \pm 0.76^{\mathrm{a}}$ \\
T2 & $16.99 \pm 1.25^{\mathrm{a}}$ & $17.16 \pm 2.13^{\mathrm{a}}$ & $19.44 \pm 1.39^{\mathrm{a}}$ \\
T3 & $15.56 \pm 0.36^{\mathrm{ab}}$ & $16.88 \pm 1.02^{\mathrm{a}}$ & $19.24 \pm 1.28^{\mathrm{a}}$ \\
T4 & $14.38 \pm 1.65^{\mathrm{b}}$ & $14.69 \pm 0.37^{\mathrm{b}}$ & $18.43 \pm 1.40^{\mathrm{a}}$ \\
T5 & $13.84 \pm 0.45^{\mathrm{b}}$ & $13.82 \pm 0.05^{\mathrm{bc}}$ & $17.73 \pm 0.63^{\mathrm{a}}$ \\
T6 & $13.44 \pm 1.36^{\mathrm{b}}$ & $12.04 \pm 0.95^{\mathrm{c}}$ & $17.16 \pm 1.30^{\mathrm{a}}$ \\
SEM & 0.68 & 0.69 & 0.67 \\
\hline
\end{tabular}

a-c means within the same column with different superscripts letters are different $(\mathrm{p}<0.05)$.

T1, T2 and T3: Treatments for soybean oil/ soybean oil with ZAD 0.5kg/ton and soybean oil with AmPhi-BACT 0.5kg/ton. T4, T5andT6: Treatments for palm oil/ palm oil with ZAD 0.5kg/ton and palm oil with AmPhi-BACT 0.5kg/ton. Means \pm standard deviation. SEM: standard error of means.

From the same Table (4), it can be found that no significant differences were found in the reduction in thickness\% of nuggets of T2 and T3 groups and nuggets of T1and T6 groups. Slight significant difference was found in nuggets ofT4 andT5. Addition of vegetable oils and commercial multi enzymes feed additives had no significant effect on shrinkage $\%$ of nuggets samples. These results are consonance with that obtained by Omojola et al. (2014) they reported that there was no significant effect on the meat characteristics of broiler chickens fed on diets (soybean and sesame) supplemented with or without microbial phytase. Also, Dalólio et al. (2015) found that enzyme supplementation in diets based on corn and soybean meal did not influence the parameters of chicken meat quality. The same results were found by Pekel et al. (2012). Color measurements of chicken nuggets fed on different dietary oils and commercial multi- enzyme feed additives shown in Table (5). No significant differences were found in $L^{*}$ value between dietary treatments except for nugget of T1. Also, data showed no significant differences were found in $a^{*}$ value between nuggets of T1, T3and T4.Slight difference was found between nuggets of T5and T6.No significant differences were found in $b *$ value between nuggets of T2, T4 and T6. The differences between the other nuggets samples were not significant. These results are close to that obtained by Pekel et al. (2012) they found that breast meat color were not affected by the dietary fat source. Also, Zakaria et al. (2010) they reported that dietary enzyme had no effect on the broiler chicken meat color. Dalólio et al. (2015) found that enzyme supplementation in diets based on corn and soybean meal did not influence the color parameters of chicken meat.

Table.5: Color measurements of chicken nuggets

\begin{tabular}{cccc}
\hline & \multicolumn{3}{c}{ Parameters } \\
\cline { 2 - 4 } Treatments & $L$ & $a$ & $b$ \\
\cline { 2 - 4 } T1 & $58.97 \pm 0.89^{\mathrm{b}}$ & $4.05 \pm 1.33^{\mathrm{ab}}$ & $15.29 \pm 0.66^{\mathrm{c}}$ \\
T2 & $63.35 \pm 1.15^{\mathrm{a}}$ & $4.62 \pm 0.87^{\mathrm{a}}$ & $17.27 \pm 0.62^{\mathrm{a}}$ \\
T3 & $56.67 \pm 0.68^{\mathrm{a}}$ & $4.09 \pm 0.15^{\mathrm{ab}}$ & $15.94 \pm 0.28^{\mathrm{bc}}$ \\
T4 & $62.21 \pm 2.16^{\mathrm{a}}$ & $4.11 \pm 0.35^{\mathrm{ab}}$ & $17.03 \pm 0.14^{\mathrm{a}}$ \\
T5 & $63.56 \pm 2.05^{\mathrm{a}}$ & $3.52 \pm 0.33^{\mathrm{bc}}$ & $15.98 \pm 0.35^{\mathrm{b}}$ \\
T6 & $63.18 \pm 1.16^{\mathrm{a}}$ & $2.79 \pm 0.08^{\mathrm{c}}$ & $16.76 \pm 0.39^{\mathrm{a}}$ \\
SEM & 0.87 & 0.28 & 0.21 \\
\hline
\end{tabular}

${ }^{\mathrm{a}-\mathrm{c}}$ Means within the same column with different superscripts letters are different $(\mathrm{p}<0.05)$. T1, T2 and T3: Treatments for soybean oil/ soybean oil with ZAD 0.5kg/ton and soybean oil with AmPhi-BACT 0.5kg/ton. T4, T5andT6: Treatments for palm oil/ palm oil with ZAD $0.5 \mathrm{~kg} /$ ton and palm oil with AmPhi-BACT 0.5kg/ton. Means \pm standard deviation. SEM: standard error of means. 


\section{CONCLUSION}

The purpose of the current study was to evaluate the quality characteristics of chicken nuggets processed from broiler chicken fed on different type of vegetable oils and feed additives. The addition of soybean oil and palm oil as fat sources for use in chicken diets in combination with feed additives (enzymes) had no negative effects on the quality characteristics of chicken nuggets.

\section{REFERENCES}

[1] Abdulla, N. R., Loh, T.C., Akit, H., Sazili, A.Q., Foo, H.L., Mohamad, R.,\& Abdul Rahim, R., Ebrahimi, M., Sabow, A.B. (2015). Fatty acid profile, cholesterol and oxidative status in broiler chicken breast muscle fed different dietary oil sources and calcium levels. South African Journal of Animal Science, 45(2), 153-163.

[2] AOCS.(1998). American Oil Chemists' Society. Official method Cd 19-90. 2-Thiobarbituric acid value. Direct method. In: Firestone D, editor. Official Methods and Recommended Practices of the American Oil Chemists' Society, 5th ed. Champaign, p.3.

[3] Ayed, H. B., Attia, H., \& Ennouri, M. (2015). Effect of oil supplemented diet on growth performance and meat quality of broiler chickens. Advanced Techniques in Biology \& Medicine, 4, 1- 4.

[4] Berry, B.W. (1993). Fat level and freezing temperature affect sensory, shear cooking and composition properties of ground beef patties. Journal of Food Science, 58 (1), 34-42.

[5] CIE. Commission International de L'Eclairage (1976) Official recommendations on uniform colour spaces. Colour difference equations and metric colour terms, Suppl. No. 2. CIE Publication No. 15 Colourimetry. Paris.

[6] Dalólio, F. S., Vaz, D. P., Moreira, J., Albino, L. F. T. \& Valadares, L. R.(2015). Carcass characteristics of broilers fed enzyme complex. Biotechnology in Animal Husbandry, 31 (2), 153-162.

[7] Duncan, D. B. (1955). Multiple range and multiple Ftests. Biometrics, 11, 1- 42.

[8] Hood, D. E. (1980). Factors affecting the rate of metmyoglobin accumulation in prepackaged beef. Meat Science, 4 (4), 47-50.

[9] Howe, P., Meyer, B., Record S., Baghurst, K., (2006). Dietary intake of long-chain $\omega-3$ polyunsaturated fatty acids: contribution of meat sources. Nutrition. 22, 47-53.

[10] Lázaro, R.,García, M.,Araníbar, M.J.,\& Mateos, G.G. (2003). Effect of enzyme addition to wheat-, barleyand rye-based diets on nutrient digestibility and performance of laying hens. British Poultry Science, 44, 256-265.

[11] Murphy, E. W., Criner, P. E.,\& Grey, B. C. (1975). Comparison of methods for calculating retentions of nutrients in cooked foods. Journal of Agricultural Food Chemistry, 23, 1153-1157.

[12] NRC.(1994). National Research Council. Nutrient Requirements of Poultry 9th Ed. Composition of poultry feedstuffs. National Academy Press, Washington, DC, USA.

[13] Naveena, B. M., Muthukumar, M., Sen, A. R., Babji, Y.,\& Murthy, T. R. K. (2006). Quality characteristics and storage stability of chicken patties formulated with finger millet flour (Eleusinecoracana). Journal of Muscle Foods, 17 (1), 92-104.

[14] Nayak, N.K., Pathak, V., Singh, V.P., Goswami, M., Bharti, S.K. (2015). Quality of Carrageenan Incorporated Low Fat Chicken Nuggets during Refrigerated Storage at $4^{\circ} \mathrm{C}$. Livestock Research International, 3 (1), 7-13.

[15] Omojola, A. B., Otunla, T. A., Olusola, O. O., Adebiyi, O. A., \& Ologhobo, A. D. (2014). Performance and Carcass Characteristics of Broiler Chicken Fed Soybean and Sesame/Soybean Based Diets Supplemented With or Without Microbial Phytase. American Journal of Experimental Agriculture, 4 (12), 1637-1648.

[16] Pekel, A. Y., Demirel, G., Midilli, M., Yalcintan, H., Ekiz, B.,\& Alp, M. (2012). Comparison of broiler meat quality when fed diets supplemented with neutralized sunflower soapstock or soybean oil. Poultry Science, 91, 2361-2369.

[17] Rymer, C., \& Givens, D.I. (2005). Omega-3 fatty acid enrichment of edible tissue of poultry: A review. Lipids, 40, 121-130.

[18] SAS, 2000. User's Guide Statistics. SAS Institute, Inc., Cary, N.C., USA.

[19] Wang, W., Wang, Z., Yang, H., Cao, Y., \&Zhu, X., Zhao, Y. (2013). Effects of phytase supplementation on growth performance, slaughter performance, growth of internal organs and small intestine and seum biochemical parameters of broilers. Open Journal of Animal Science, 3 (3), 236-241.

[20]Zakaria, H. A.H., Mohammad, A. R. J.,\& Abu Ishmais, M. A. (2010). The Influence of Supplemental Multi-enzyme Feed Additive on the Performance, Carcass Characteristics and Meat Quality Traits of Broiler Chickens. International Journal of Poultry Science, 9 (2), 126-133. 